\title{
Varhaista johdon konsultointia
}

Mengzi, veljellisyyden tie (2020). Suomentanut ja toimittanut Jyrki Kallio. Gaudeamus. 392 sivua.

MESTARI MENG ELI MENGZI (372-289 eaa.) oli Kungfutsen (551-479 eaa.) tärkein seuraaja ja ajattelun kehittäjä. Suomentaja ja toimittaja Jyrki Kallio luonnehtii kungfutselaisuutta perinnäistapoja ja sosiaalisten roolien mukaista käytöstä painottavaksi yhteiskunnallis-eettiseksi opiksi, joka tähtää itsen jalostamiseen ja hyvän hallinnon edistämiseen. Kun edistys nähdään paluuna vanhoihin hyviin tapoihin, oppi ei ole radikaaleimpia, mutta sen pohjalta on voitu paitsi silittää valtaapitäviä myötäkarvaan myös kritisoida heitä.

Samoihin aikoihin kuin Aristoteles kirjoitti hyveistä Ateenassa, Mengzi pohti tärkeimpiä hyveitä seuraavaan tapaan: "Myötätuntoisuus on veljellisyyden itu, häpeän ja halveksunnan tunne on oikeamielisyyden itu, vaatimaton ja mukautuvainen mieli on perinnäistapojen itu ja kyky erottaa oikea väärästä on viisauden itu (s. 72-73)."

Seitsemäs Han-keisari määräsi vuonna 136 eaa. kungfutselaisuuden klassikkokirjoitukset valtakunnan viralliseksi ideologiaksi, paljolti Mengzin kirjoitusten ansiosta. Kungfutse oli eräänlainen Han-dynastian suojeluspyhimys, ja kungfutselaisuuden asema säilyi, vuoteen 1905 asti, jolloin virkatutkintojärjestelmä lakkautettiin. Vuonna 1911 lakkautettiin keisarin valta. Nykyaikaan sovitettu ja Mengzin perintöön nojaava kungfutselaisuus on Kiinassa jälleen nousussa.

\section{JOKAISESSA MAHDOLLISUUS} HYVÄÄN

Kungfutsen ei tiedetä lausuneen ihmisluonnosta mitään, mutta Mengzi on tunnettu käsityksestään, että jokaisessa piilee synnynnäinen mahdollisuus hyvään. Tämä oppi ei ollut aikansa valtavirtaa, ja Mengziä voi pitää idealistina, mutta samalla hän tuntui tunnistavan kaksinaamaisuutta. Hän ei voinut välttyä aikansa hallintapuheelta, mutta uskoi selviävänsä siitä:

"Valheellisista sanoista tiedän, mitä ne piilottavat; viekoittelevista sanoista tiedän, millainen ansa niissä piilee; petollisista sanoista tiedän, miten harhaan ne vievät; välttelevistä sanoista tiedän, mitä niistä puuttuu. Jos hallitsija synnyttää sellaisia sanoja sydämessään, ne tuovat vahinkoa hänen hallinnolleen; jos hän panee niiden mukaisen hallinnon täytäntöön, ne tuottavat vahinkoa asioiden hoidolle" (s. 68).

Muihin koulukuntiin Mengzi suhtautui umpimielisesti. Hän tuomitsi esimerkiksi kaiken kattavaa ja vastavuoroista rakkautta julistavan Mo Din: "Mon mukaan kaikkien tulisi rakastaa kaikkia, mikä tarkoittaa, että meillä ei tulisi olla isiä. Mutta ilman hallitsijoita ja ilman isiä meistä tulisi pelkkiä luontokappaleita."
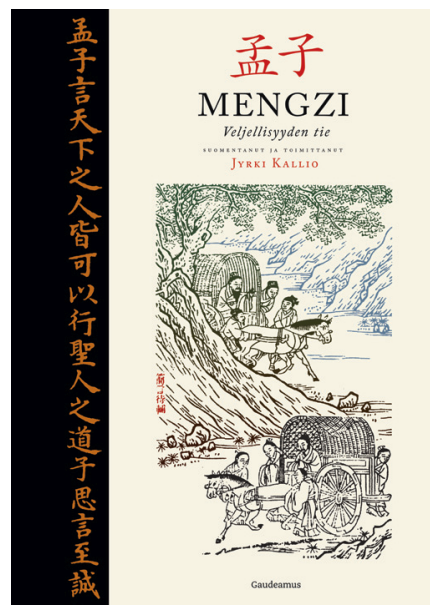

\section{JOHDON KONSULTTI}

Noin vuonna 1000 eaa. Zhouvaltio kukisti aiemman valtakeskittymän ja keskitti vallan itselleen. Kuningas oli itseoikeutettu Taivaan poika, mutta keskusvallan vähitellen heiketessä julistettiin kilpailevia kuningaskuntia, ja Mengzin aikaan elettiin sotivien valtakuntien aikakautta. Kungfutsen tavoin Mengzi ihaili mennyttä, mutta toisin kuin oppi-isänsä, hän ennusti uuden kulta-ajan tuloa.

Mengzi halusi ja ajoittain onnistuikin puhumaan suoraan hallitsijoille. Kukaan aikalaishallitsija ei hänen mielestään voinut olla kunnollinen Taivaan poika olematta moraalinen esikuva muille. Esikuvallisilla on kyky saada muutkin muuttumaan. Liangin kuningas Huille Mengzi sanoi: "Kun ylhäiset ja alhaiset kahmivat toistensa kustannuksella itselleen hyötyä, valtakunta joutuu vaaraan." Kuninkaan tulee puhua vain veljellisyydestä ja oikeamielisyydestä, ei hyödystä. 
Veljellisyyden lisäksi toinen tärkeä Mengzin käsite on 'kuninkaiden tie', hyvä hallinto. Kungfutse ja hänen seuraajansa eli niin sanotut ru-oppineet pyrkivät edistämään oikeamielistä hallintoa vetoamalla muinaisten ja myyttisten hallitsijoiden esimerkkeihin. Muinaiset pyhät miehet jakoivat etuisuuksia rahvaan hyväksi, ja ensimmäiset kuninkaat opettivat maanviljelyksen ja muut tarpeelliset taidot. Kuninkaat johdattivat ihmiset "yhdessä elämisen ja yhdessä viljelemisen tielle", järjestäytyneeseen yhteiskuntaan. Kun seuraa ensimmäisten kuninkaiden oppia, rakkaus ja yhteisöllisyys vallitsevat.

Qin kuningas Luanille Mengzi lausui: "Joka iloitsee yhdessä rahvaan kanssa, saa rahvaan iloitsemaan kanssaan; joka kantaa rahvaan huolet, saa rahvaan kantamaan omat huolensa." Herttua Wenille Mengzi sanoi: "Jos rahvaalla on vakaa toimeentulo, heillä on vakaa sydän; ilman vakaata toimeentuloa heidän sydämensä ei ole vakaa."

Herttua Mu sai puolestaan kuulla: "Se, mitä teet, kääntyy itseäsi kohtaan. Se, mitä teette rahvaalle tänään, kääntyy myöhemmin teidän osaksenne.” Mengzi tuki johtajia myös priorisoinnin taidossa: ”Jos jättää tekemättä merkityksettömiä asioita nyt, voi myöhemmin tehdä merkityksellisiä asioita.”

\section{TARINA ORAIDEN NYPPIJÄSTÄ}

Mengzi varoitti johtohenkilöitä asioiden keinotekoisesta nopeuttamisesta ja "tehostamisesta". Hänen tunnetuimpiin kuuluvassa tarinassaan muuan mies oli huolissaan oraistaan, jotka eivät kasvaneet riittävän nopeasti. Mies ratkaisi asian nyppimällä oraita ylöspäin ja kotiin palattuaan kertoi ylpeänä talonväelle auttaneensa oraita kasvamaan. Miehen poika ryntäsi pellolle ja näki kauhukseen kaikkien oraiden kuihtuneen. Mengzi toteaa lakonisesti: "Taivaan alla ovat harvassa ne, jotka eivät pakota oraita kasvamaan."

Ihmisten väliset suhteet tuli pitää järjestyksessä, eli hallitsijan tuli noudattaa omaa tietään, alamaisen omaansa: "Isän ja pojan välillä vallitkoon kiintymys, ruhtinaan ja alamaisen välillä vallitkoon oikeamielisyys, miehen ja vaimon välillä vallitkoon eroavaisuus, vanhempien ja kasvavien välillä vallitkoon ikäjärjestys, ja kumppanien ja toverien välillä vallitkoon luottamus." Torut ja kehut kuuluvat ystävyyteen, mutta eivät isien ja poikien suhteisiin. Omasta väestä piti huolehtia ehdoitta, naapurin asioihin puuttuminen ei ollut viisasta.

Asiat pysyvät järjestyksessä, kun kaikella ja kaikilla on paikkansa. Henkisen työn tekijät olivat ruumiillisen työn tekijöiden yläpuolella: ” $\mathrm{Ne}$, jotka vaivaavat mieltään, hallitsevat muita, niitä, jotka vaivaavat ruumistaan, muut hallitsevat. Ne, joita hallitaan, ruokkivat muut; niitä jotka hallitsevat, muut ruokkivat. Tämä on säännönmukaisuus kaikkialla Taivaan alla.” Toisaalta Mengzi varoitti valtiaita liiasta köyhien riistämisestä, koska tällöin "rahvas katsoo ylempiään alta kulmiensa ja solvaa heitä sekä lankeaa lopuksi huonoihin tekoihin”.
Sotivien valtakuntien aikaan herrasmiehet ja mahtimiehet kuuluivat yleensä ylimystöön tai ritarisäätyyn ja olivat rahvaanmiesten yläpuolella. Vapaat miehet eli ritarit olivat aatelittomien neljän säädyn - ritarit, kauppiaat, talonpojat ja käsityöläiset - ylimpiä. Köyhillä ei satoihin vuosiin ollut asiaa korkeisiin virkoihin.

\section{IKKUNA TUHANSIEN VUOSIEN} PÄÄHÄN

Mengzi-teos on ikkuna Kiinan neljännen ajanlaskua edeltävän vuosisadan tapoihin ja ajatteluun. Suomentajan ja toimittajan työ on saanut ansaittua huomiota: Jyrki Kallio taustoittaa Mengzin kirjoituksia monin tavoin, perustelee suomennoksensa ratkaisut ja tuo erilaiset tulkinnan mahdollisuudet esiin. Kiinaa ymmärtäviä ilahduttanee alkutekstin liittäminen osaksi editiota.

Jonkin verran kysymyksiä on herättänyt Mengzille keskeisen ren-käsitteen suomentaminen 'veljellisyydeksi'. Buddhalaiset pitävät Kallion mukaan reniä yhteneväisenä kaiken kattavaa myötätuntoa kuvaavan karuna-käsitteen kanssa. Ren on Kiinan runoutta tutkivan Tero Tähtisen mukaan perinteisesti käännetty hyvyydeksi, humaaniudeksi tai kunniallisuudeksi.

\section{JUSSI ONNISMAA}

FT, dosentti, työnohjaajakouluttaja, tietokirjailija 